Supporting Information

\title{
Unraveling V(V)-V(IV)-V(III)-V(II) Redox Electrochemistry in Highly Concentrated Mixed Acidic Media for a Vanadium Redox Flow Battery: Origin of the Parasitic Hydrogen Evolution Reaction
}

\author{
Jihye Lee, Jules Tshishimbi Muya, Hoeil Chung, and Jinho Chang* \\ Department of Chemistry and Research Institute for Natural Sciences, Hanyang University, \\ 222 Wangsimni-ro, Seongdong-gu, Seoul 04763, Republic of Korea
}

*E-mail: jhcechem@hanyang.ac.kr 


\section{Table of Contents}

Table S1

$R_{\mathrm{s}}$ and $C_{\mathrm{dl}}$ of the electrochemical cell in solutions containing $6 \mathrm{M} \mathrm{H}_{2} \mathrm{SO}_{4}+2.5 \mathrm{M}$ $\mathrm{HCl}$ with various concentration of either $\mathrm{VOSO}_{4}$ or $\mathrm{VCl}_{3}$.

\section{Figure S1}

The SEM image and EDS curve from a counter Pt wire.

Figure $\mathbf{S 2}$

The CVs in the solutions with $C_{V O^{2+}}=35,50$, and $75 \mathrm{mM}$ at $v$ of $0.02,0.05,0.1$, and $0.5 \mathrm{~V} / \mathrm{s}$.

Figure S3

The LSVs in solutions with different $C_{V^{3}}$ at $v$ of $0.05,0.1,0.3,0.5,1 \mathrm{~V} / \mathrm{s}$, and the corresponding best-fit simulation results based on the suggested ECEC scheme shown in Figure 4d.

\section{Figure S4}

The CVs in solution containing various $C_{V^{3+}}$ at different $v$, and the corresponding best-fit simulation result based on $\mathrm{V}^{3+}+\mathrm{e}^{-} \rightleftharpoons \mathrm{V}^{2+}$.

Figure S5

The CA in solution without $\mathrm{V}^{3+}$ at constantly applied $-1.1 \mathrm{~V}$ for $1000 \mathrm{~s}$.

Figure S6

The CA at constantly applied $1.1 \mathrm{~V}$ for $1000 \mathrm{~s}$ to oxidize $\mathrm{V}^{3+}$ to $\mathrm{VO}_{2}{ }^{+}$on a working electrode in solution with $C_{V^{3+}}=50 \mathrm{mM}$.

Figure $\mathbf{S 7}$

The ex-situ energy dispersive spectrum of a graphite electrode surface after electro-reduction of $\mathrm{V}^{3+}$ and $\mathrm{VO}^{2+}$ for $3600 \mathrm{~s}$ in solution with $C_{V^{3+}}=50 \mathrm{mM}$ and $C_{V O^{2+}}$ of $50 \mathrm{mM}$ and those from a pristine graphite electrode.

Figure S8

(a)-(f) The CAs at a constantly applied $-1.1 \mathrm{~V}$ for $1000 \mathrm{~s}$ on a GC electrode from acidic solutions with $C_{V^{3+}}=50 \mathrm{mM}$ to show the large variance of the reduction current attributed to HER by $\mathrm{V}(\mathrm{II})_{\text {catalyst }}$.

Figure S9

The CVs at various $v$ measured in solutions with $C_{V O^{2+}}=75 \mathrm{mM}$

Figure S10

The geometric models for solvated (a) $\mathrm{V}^{\mathrm{p}+}$ and (b) $\mathrm{VO}^{\mathrm{q}+}$ and (c) the corresponding atom numbering.

Table S2

Electronic states, molecular point groups, lowest frequencies in $\mathrm{cm}^{-1}$, and V-O bond distances in angstrom units of solvated vanadium cations and vanadium oxide neutral and cation species computed with B3LYP/6-31G(d).

Figure S11

Optimized geometries of (a) protonated vanadium cations and (b) vanadium oxide species surrounded by water molecules computed using B3LYP/6-31+G(d,p). 
Table $\mathrm{S} 1 . R_{\mathrm{S}}$ and $C_{\mathrm{dl}}$ of the electrochemical cell in solutions containing $6 \mathrm{M} \mathrm{H}_{2} \mathrm{SO}_{4}+2.5 \mathrm{M}$ $\mathrm{HCl}$ with various concentration of either $\mathrm{VOSO}_{4}$ or $\mathrm{VCl}_{3}$.

\begin{tabular}{cccc}
\hline Concentration & Species & $R_{\mathrm{s}}(\Omega)$ & $C_{\mathrm{dl}}(\mu \mathrm{F})$ \\
\hline $35 \mathrm{mM}$ & $\mathrm{VOSO}_{4}$ & $6.26 \pm 4.41$ & $0.86 \pm 0.05$ \\
$50 \mathrm{mM}$ & $\mathrm{VOSO}_{4}$ & $9.26 \pm 5.57$ & $0.57 \pm 0.13$ \\
$75 \mathrm{mM}$ & $\mathrm{VOSO}_{4}$ & $7.00 \pm 3.79$ & $0.55 \pm 0.32$ \\
$35 \mathrm{mM}$ & $\mathrm{VCl}_{3}$ & $8.83 \pm 2.40$ & $0.43 \pm 0.22$ \\
$50 \mathrm{mM}$ & $\mathrm{VCl}_{3}$ & $6.03 \pm 0.90$ & $0.52 \pm 0.33$ \\
$75 \mathrm{mM}$ & $\mathrm{VCl}_{3}$ & $11.5 \pm 10.15$ & $0.75 \pm 0.91$ \\
\hline
\end{tabular}




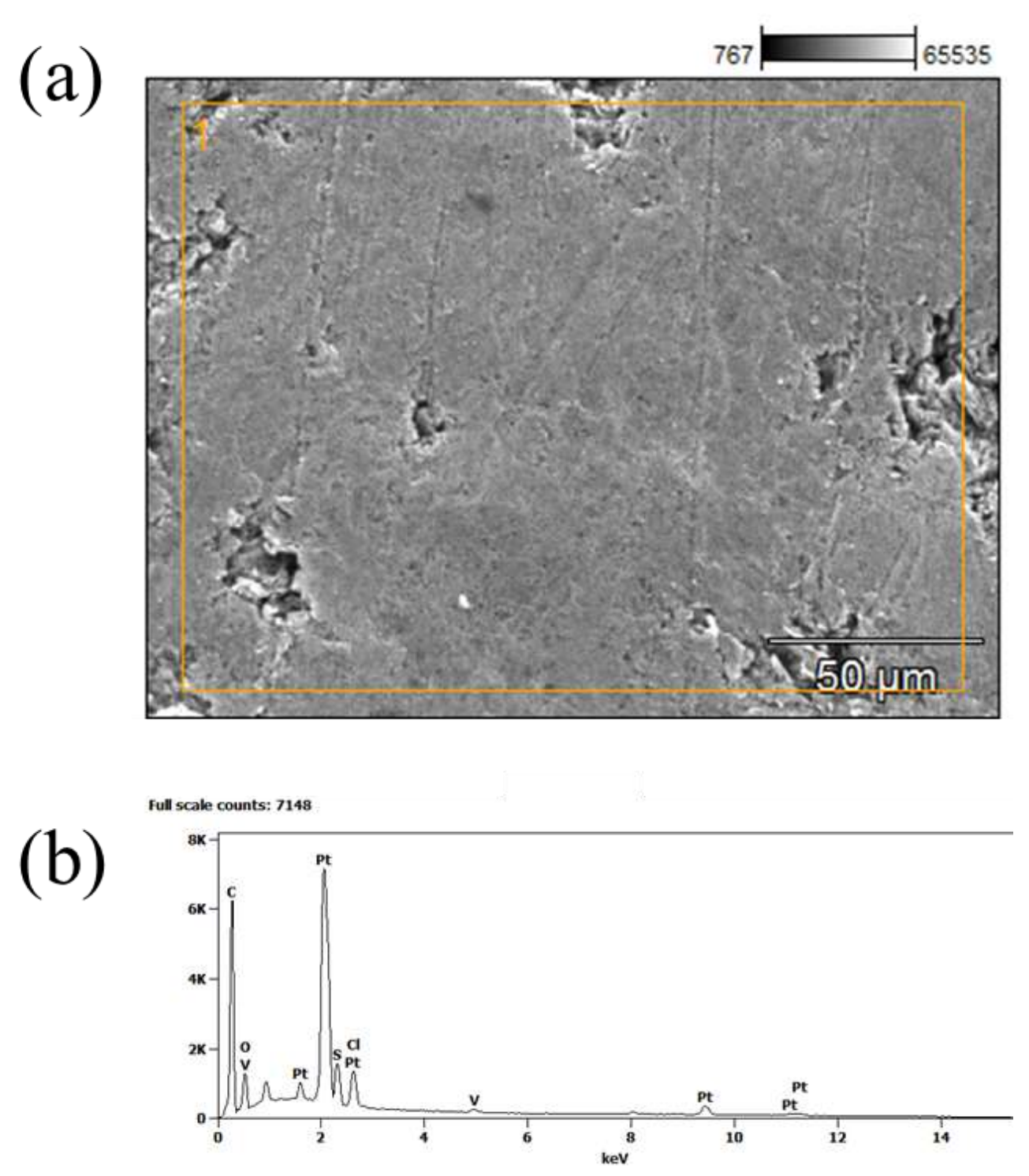

Figure S1. (a) The SEM image and (b) corresponding EDS curve from a graphite working electrode after electro-reduction of $\mathrm{V}^{3+}$ in $2.5 \mathrm{M} \mathrm{H}_{2} \mathrm{SO}_{4}+6 \mathrm{M} \mathrm{HCl}+50 \mathrm{mM} \mathrm{V}^{3+}$ when a $\mathrm{Pt}$ wire was used as a counter electrode in a three-electrode electrochemical cell configuration. 

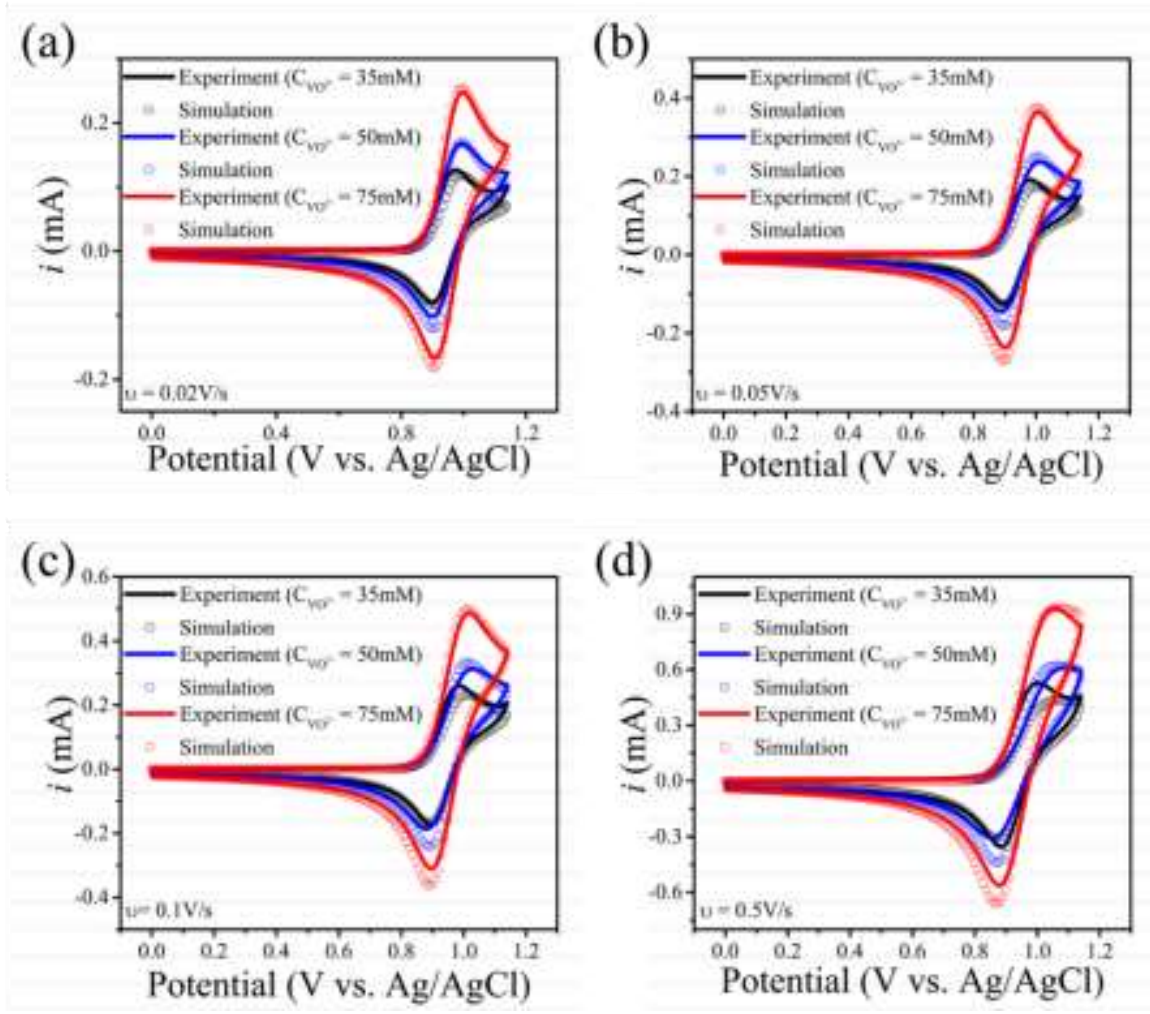

Figure S2. The CVs in solutions with $C_{V O^{2+}}=35,50$, and $75 \mathrm{mM}$ at $v$ of (a) 0.02 , (b) 0.05 , (c) 0.1 , and (d) $0.5 \mathrm{~V} / \mathrm{s}$ and the corresponding best-fit simulation results based on the suggested EC/EC scheme in Figure 1c. 

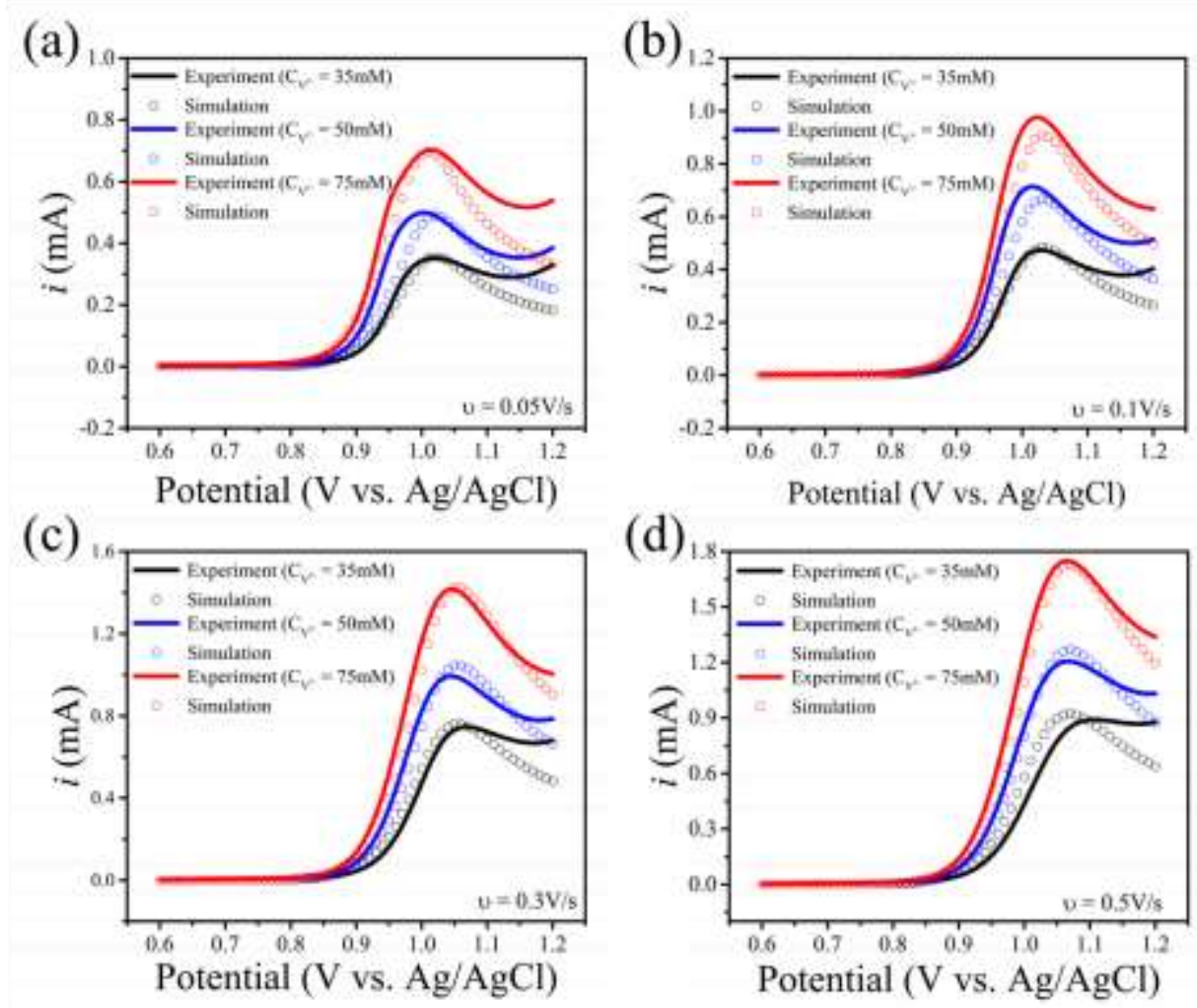

Figure S3. The LSVs in solutions with different $C_{V^{3+}}$ at $v$ values of (a) 0.05 , (b) 0.1 , (c) 0.3 , (d) $0.5 \mathrm{~V} / \mathrm{s}$ and the corresponding best-fit simulation results based on the suggested ECEC scheme shown in Figure 4d. 

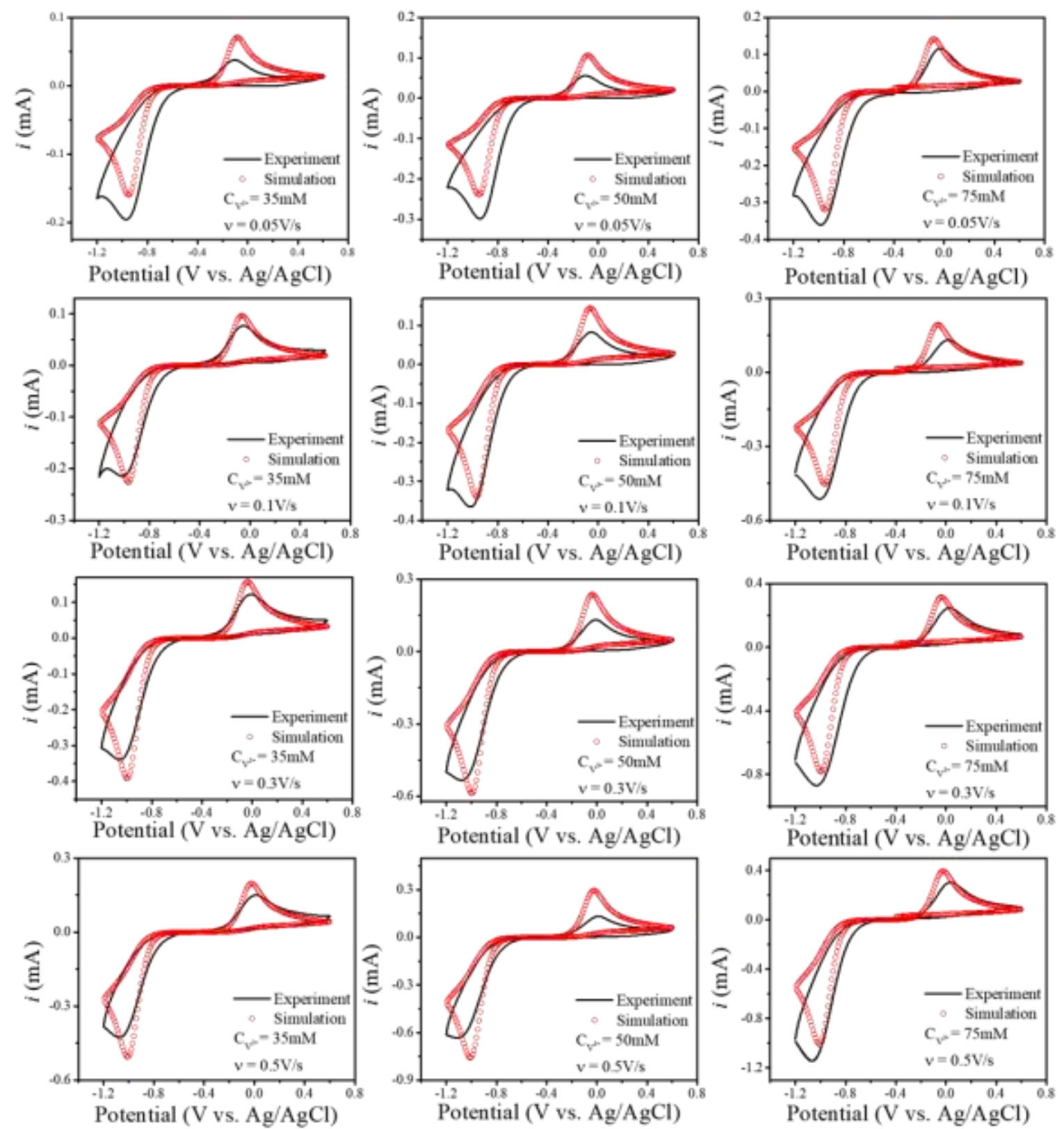

Figure S4. The CVs in solution containing various $C_{V^{3+}}$ at different $v$ and the corresponding best-fit simulation result based on $\mathrm{V}^{3+}+\mathrm{e}^{-} \rightleftharpoons \mathrm{V}^{2+}$. 


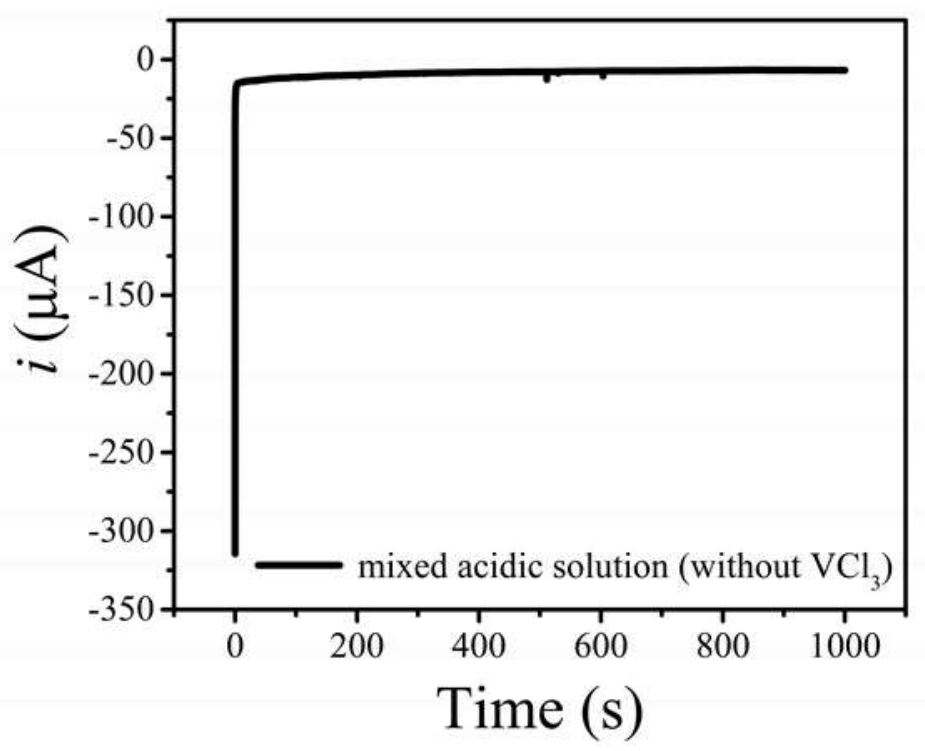

Figure S5. The CA in solution without $\mathrm{V}^{3+}$ under constantly applied $-1.1 \mathrm{~V}$ for $1000 \mathrm{~s}$.

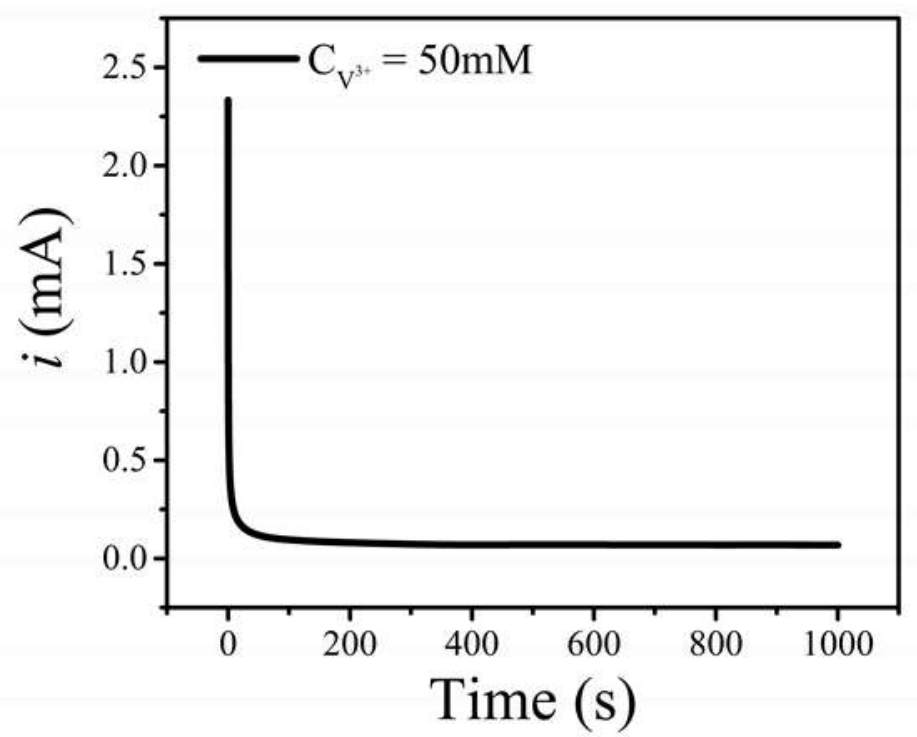

Figure S6. The CA under constantly applied $1.1 \mathrm{~V}$ for $1000 \mathrm{~s}$ to oxidize $\mathrm{V}^{3+}$ to $\mathrm{VO}_{2}{ }^{+}$on a working electrode in solution with $C_{V^{3+}}=50 \mathrm{mM}$. 
(a)
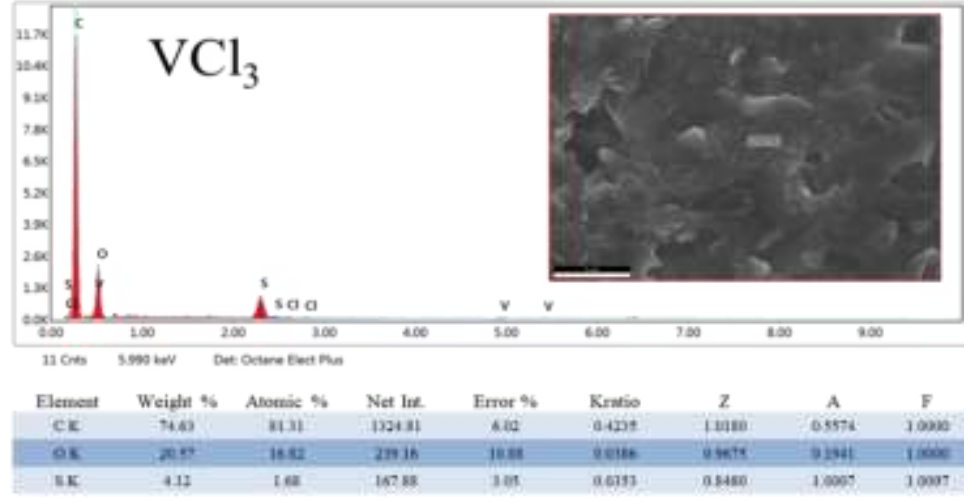

(b)

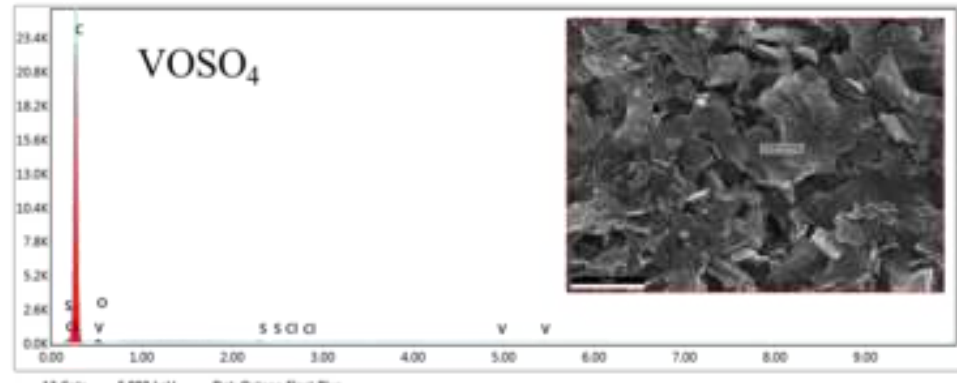

(c)
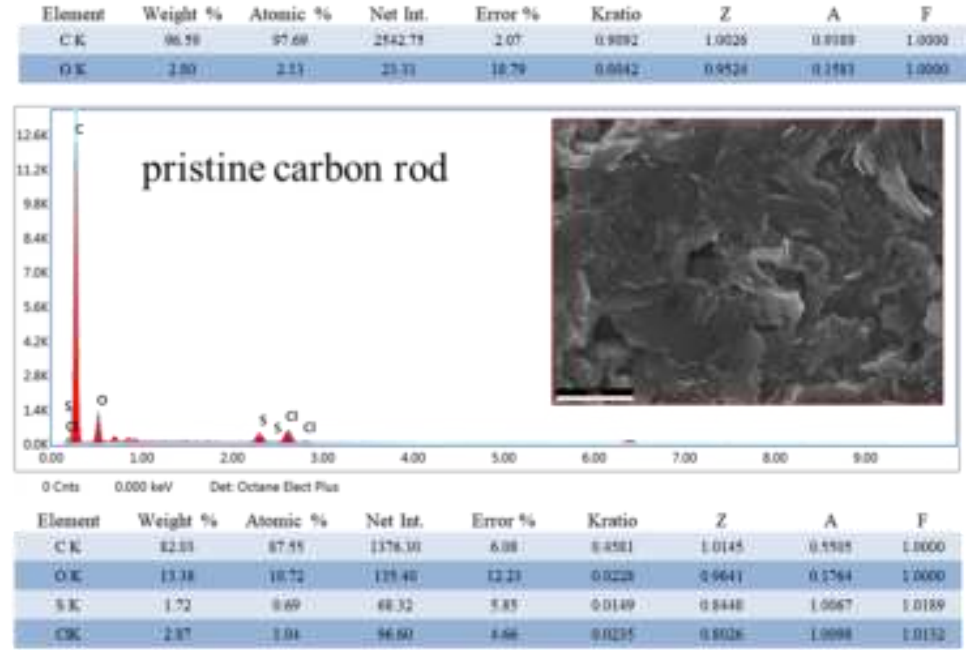

Figure S7. The ex-situ energy dispersive spectrum of a graphite electrode surface after electro-reduction of (a) $\mathrm{V}^{3+}$ and (b) $\mathrm{VO}^{2+}$ for $3600 \mathrm{~s}$ in solution with $C_{V^{3+}}=50 \mathrm{mM}$ and $C_{\mathrm{VO}^{2+}}$ of $50 \mathrm{mM}$ and (c) those from a pristine graphite electrode: (inset) SEM images of the corresponding graphite surface. 


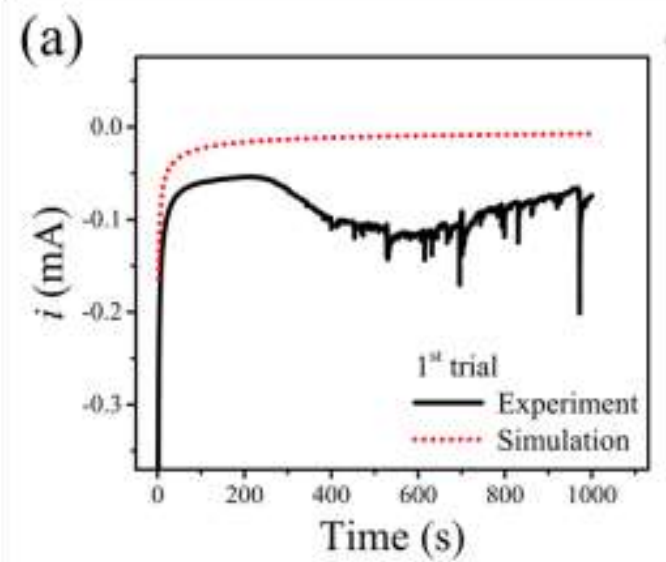

(b)
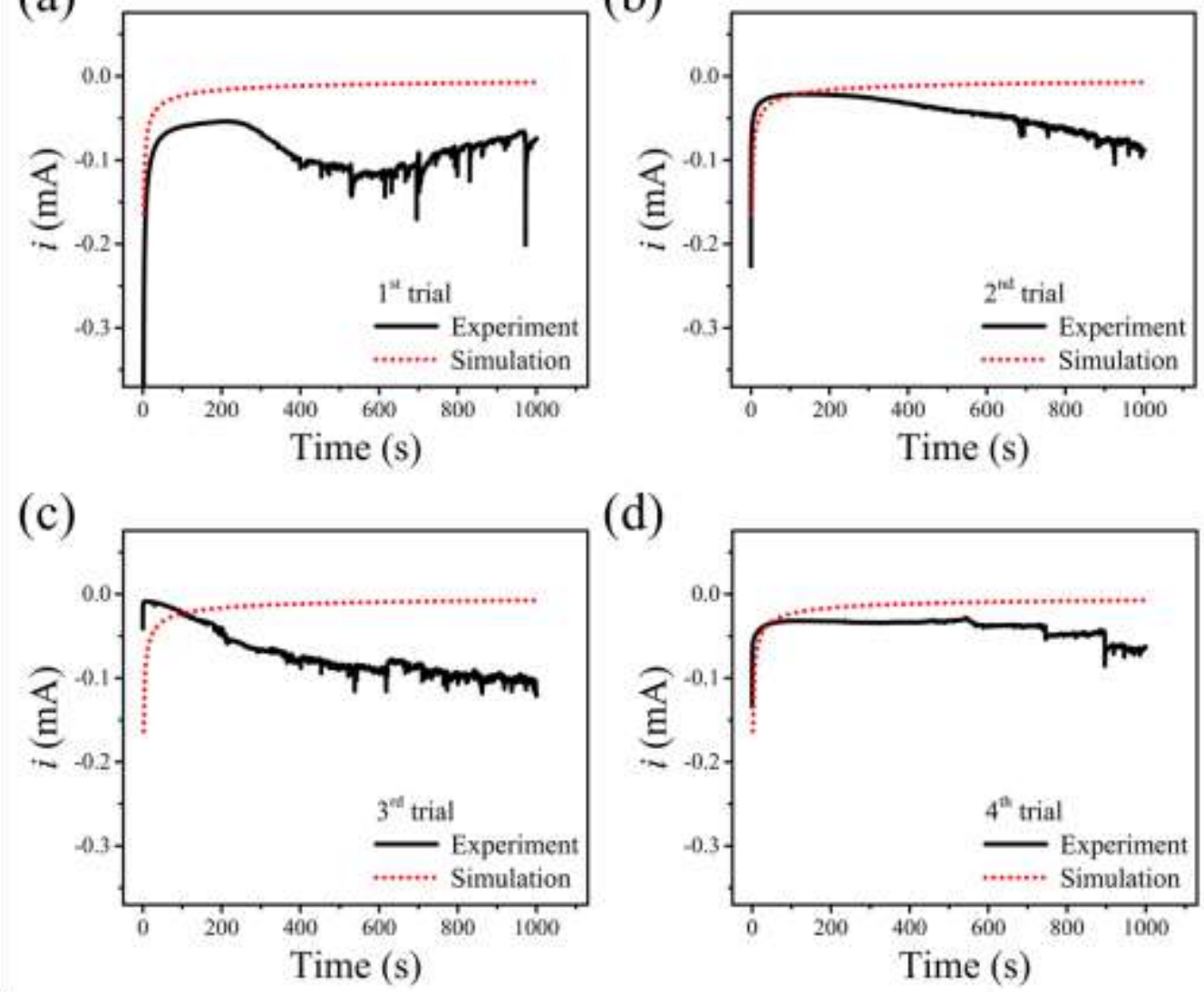

(d)

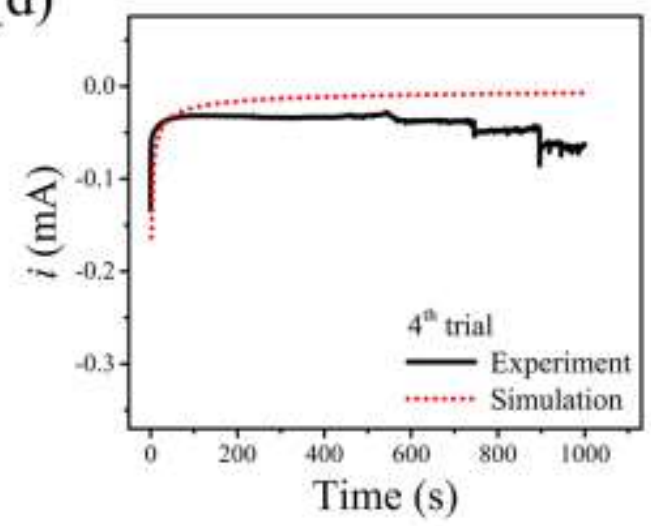

(e)
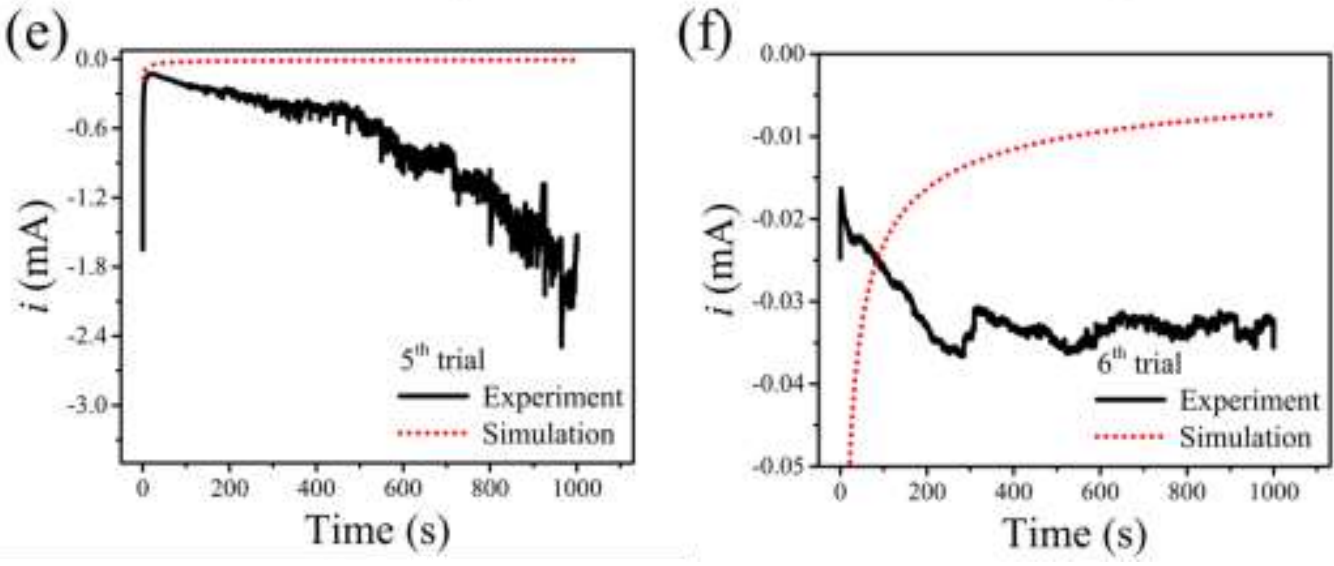

Figure S8. (a)-(f) The CAs at a constantly applied -1.1 V for $1000 \mathrm{~s}$ on a GC electrode from acidic solutions with $C_{V^{3+}}=50 \mathrm{mM}$ to show the large variance of the reduction current attributed to the HER by the V(II) catalyst. 


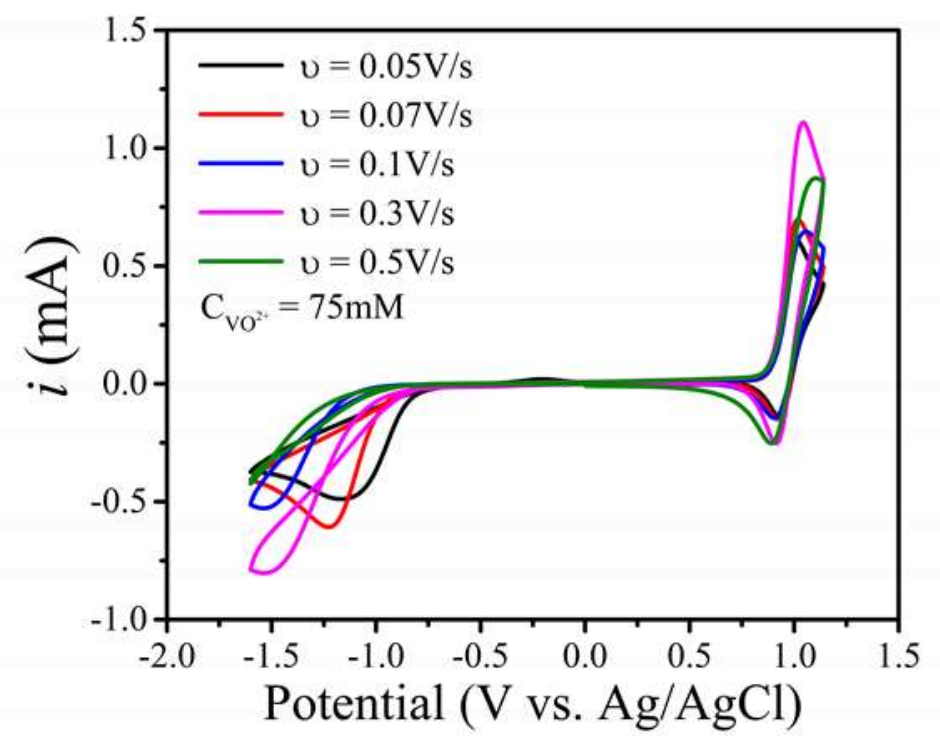

Figure S9. The CVs at various $v$ measured in solutions with $C_{V O^{2+}}=75 \mathrm{mM}$. 


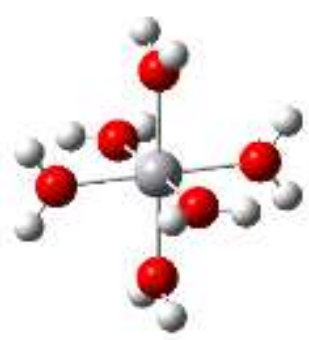

a) $\left[\mathrm{V}\left(\mathrm{H}_{2} \mathrm{O}\right)_{6}\right]^{\mathrm{p}+}$

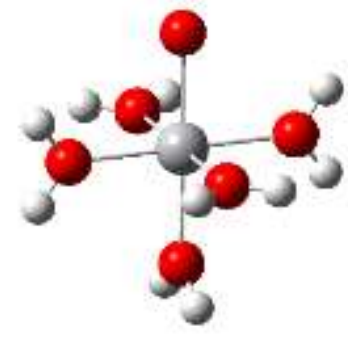

b) $\left[\mathrm{VO}\left(\mathrm{H}_{2} \mathrm{O}\right)_{5}\right]^{\mathrm{q}+}$

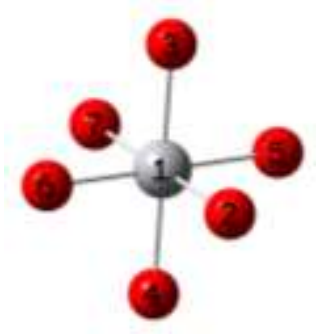

c) atom numbering

Figure S10. The geometric models for solvated (a) $\mathrm{V}^{\mathrm{p}+}$ and (b) $\mathrm{VO}^{\mathrm{q}+}$ and (c) the corresponding atom numbering. 
Table S2. Electronic states, molecular point groups, lowest frequencies in $\mathrm{cm}^{-1}$, and V-O bond distances in angstrom units of solvated vanadium cations and vanadium oxide neutral and cation species computed using B3LYP/6-31G(d).

\begin{tabular}{lccccccccc}
\hline & State & Sym & LF & V1-O2 & V1- & V1- & V1- & V1- & V1- \\
& & & & & O3 & O4 & O5 & O6 & O7 \\
\hline$\left[\mathrm{V}\left(\mathrm{H}_{2} \mathrm{O}\right)_{6}\right]^{3+}$ & ${ }^{3} \mathrm{Ag}_{\mathrm{g}}$ & $S_{6}$ & 116 & 2.502 & 2.502 & 2.502 & 2.502 & 2.502 & 2.502 \\
{$\left[\mathrm{~V}\left(\mathrm{H}_{2} \mathrm{O}\right)_{6}\right]^{2+}$} & ${ }^{4} \mathrm{Ag}$ & $T_{h}$ & 96 & 2.167 & 2.167 & 2.167 & 2.167 & 2.167 & 2.167 \\
{$\left[\mathrm{~V}\left(\mathrm{H}_{2} \mathrm{O}\right)_{6} \mathrm{H}\right]^{4+}$} & ${ }^{1} \mathrm{~A}$ & $C_{1}$ & - & 82.68 & 1.967 & 1.967 & 1.967 & 2.017 & 2.017 \\
{$\left[\mathrm{~V}\left(\mathrm{H}_{2} \mathrm{O}\right)_{6} \mathrm{H}\right]^{3+}$} & ${ }^{4} \mathrm{~A}$ & $C_{1}$ & - & 40.050 & 2.134 & 2.157 & 2.124 & 2.133 & 2.157 \\
{$\left[\mathrm{VO}\left(\mathrm{H}_{2} \mathrm{O}\right)_{5}\right]$} & ${ }^{2} \mathrm{~A}$ & $C_{1}$ & 58 & 1.602 & 2.181 & 2.352 & 2.204 & 2.237 & 2.166 \\
{$\left[\mathrm{VO}\left(\mathrm{H}_{2} \mathrm{O}\right)_{5}\right]^{+}$} & ${ }^{1} \mathrm{~A}{ }^{2}$ & $C_{s}$ & 18 & 1.595 & 2.210 & 2.303 & 2.228 & 2.228 & 2.145 \\
{$\left[\mathrm{VO}\left(\mathrm{H}_{2} \mathrm{O}\right)_{5}\right]^{2+}$} & ${ }^{2} \mathrm{~A} 1$ & $C_{2 V}$ & 109 & 1.548 & 2.091 & 2.261 & 2.091 & 2.091 & 2.091 \\
{$\left[\mathrm{VO}\left(\mathrm{H}_{2} \mathrm{O}\right)_{5} \mathrm{H}\right]^{+}$} & ${ }^{4} \mathrm{~A}$ & $\mathrm{C}_{1}$ & 84 & 2.018 & 2.185 & 2.220 & 2.191 & 2.178 & 2.185 \\
{$\left[\mathrm{VO}\left(\mathrm{H}_{2} \mathrm{O}\right)_{5} \mathrm{H}\right]^{2+}$} & ${ }^{1} \mathrm{~A}$ & $C_{1}$ & 40 & 1.697 & 2.112 & 2.129 & 2.156 & 2.156 & 2.070 \\
{$\left[\mathrm{VO}\left(\mathrm{H}_{2} \mathrm{O}\right)_{5} \mathrm{H}\right]^{3+}$} & ${ }^{2} \mathrm{~A}$ & $C_{1}$ & 124 & 1.654 & 2.023 & 2.070 & 2.048 & 2.048 & 2.023 \\
\hline
\end{tabular}




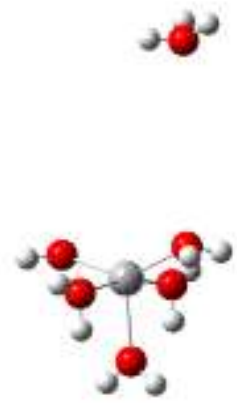

a)

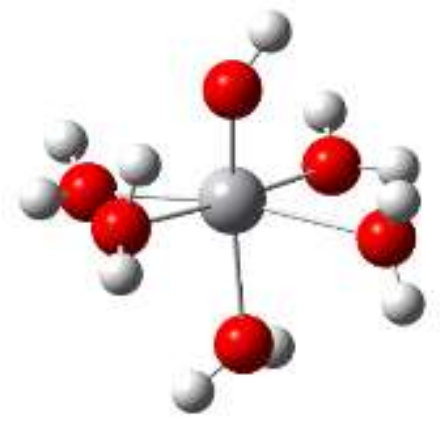

b)

Figure S11. Optimized geometries of (a) protonated vanadium cations and (b) vanadium oxide species surrounded by water molecules computed using B3LYP/6-31+G(d,p). 